JURNAL
FIT(1)PATOLOGI
I N D ON E IA
ISSN: $0215-7950$

\title{
Potensi Beberapa Isolat Bakteri Endofit untuk Pengendalian Biologi Meloidogyne graminicola pada Tanaman Padi
}

\section{Potency of Endophytic Bacterial Isolates for the Biological Control of Meloidogyne graminicola on rice}

\author{
Abdul Munif ${ }^{1 *}$, Mohammad Yadi Nurjayadi² \\ ${ }^{1}$ Departemen Proteksi Tanaman, Fakultas Pertanian, Institut Pertanian Bogor \\ ${ }^{2}$ Balai Proteksi Tanaman Perkebunan (BPTP) Pontianak, Kementerian Pertanian
}

\begin{abstract}
ABSTRAK
Meloidogyne graminicola merupakan salah satu nematoda parasit penting pada tanaman padi. M. graminicola menyebabkan gejala puru pada akar sehingga pertumbuhan tanaman terhambat dan terganggu. Pengendalian $M$. graminicola sangat penting dilakukan agar kerusakan pada tanaman padi dan penyebarannya dapat ditekan. Penelitian ini bertujuan untuk menguji potensi bakteri endofit dalam mengendalikan nematoda puru akar (NPA) M. graminicola pada tanaman padi. Empat isolat bakteri endofit asal tanaman padi, yaitu isolat Si33, Si2, Sp24, GH1, dan satu isolat asal tanaman kentang G053 diuji untuk melihat pengaruhnya terhadap mortalitas $M$. gramincola secara in vitro dan kemampuannya dalam menekan serangan $M$. graminicola pada tanaman padi di rumah kaca. Hasil uji kultur filtrat bakteri endofit secara in vitro terbukti efektif meningkatkan kematian juvenil $2 \mathrm{M}$. graminicola sebesar 99.5\% hingga 100\%. Isolat bakteri endofit juga mampu menekan jumlah puru akar pada tanaman padi dengan kisaran $42.2 \%-49.3 \%$ pada percobaan di rumah kaca. Hasil penelitian ini mengindikasikan bahwa isolat bakteri endofit yang digunakan dalam penelitian ini mempunyai potensi yang baik sebagai agens biokontrol untuk mengendalikan M. graminicola pada tanaman padi.
\end{abstract}

Kata kunci: kultur filtrat, in vitro, Meloidogyne graminicola, mortalitas, puru akar

\begin{abstract}
Meloidogyne graminicola is one of the important plant parasitic nematodes on rice plant. Control of M. graminicola on rice is very important to be done so that damage on rice and their distribution can be reduced. Endophytic bacteria for the biological control of plant parasitic nematodes have been known effectivety on several crops. The objective of this research was to study the potency of endophytic bacteria in controlling root knot nematodes $M$. graminicola on rice. Four isolates of endophytic bacteria isolated from rice plant, namely Si 33, Si2, Sp24, GH1, and G053 isolated from potato plant were tested to evaluate their effectiveness to M. graminicola on rice plants. Culture filtrate of endophytic bacteria are able to increase the mortality of second stage juveniles of $M$. graminicola from $99.5 \%$ up to $100 \%$ under in vitro test. Endophytic bacteria isolates are also able to reduce the numbers of root gall from $42.3 \%-49.3 \%$ on rice plants under greenhouse experiments. Results of this study indicated that all isolates of endophytic bacteria that are used in this experiment have potential as biocontrol agents for controlling M. graminicola on rice.
\end{abstract}

Key words: culture filtrate, greenhouse, in vitro, Meloidogyne gramnicola, mortality, root gall

*Alamat penulis korespondensi: Departemen Proteksi Tanaman, Fakultas Pertanian, Institut Pertanian Bogor, Jalan Kamper, Kampus IPB Dramaga, Bogor 16680.

Tel. 0251-8629364, Faks: 0251-8629362, Surel: abdulmunif@apps.ipb.ac.id 


\section{PENDAHULUAN}

Meloidogyne graminicola merupakan nematoda puru akar yang dapat menginfeksi tanaman padi. Gejala primer tanaman padi yang terinfeksi oleh $M$. graminicola ialah adanya puru akar yang dapat menghambat pertumbuhantanaman.M.graminicolamenjadi salah satu patogen penting yang dihadapi oleh petani padi berbagai negara di kawasan Asia dan nyata menghambat produktivitas tanaman padi. Beberapa laporan menyatakan $M$. graminicola dapat mengakibatkan kehilangan hasil yang tinggi di kawasan Asia Selatan, seperti Nepal, India, dan Bangladesh yang mencapai 80\% (Padgham et al. 2004; Pokharel et al. 2007; Jaiswal et al. 2012; Ravindra et al. 2017). Selain itu, keberadaan M. graminicola dilaporkan juga telah menginfeksi pertanaman padi di Indonesia (Erlan 1993; Nurjayadi et al. 2015). Mulyadi (1997) melaporkan serangan M. gramincola pada padi varietas IR64 menyebabkan penurunan hasil sebesar $38.5 \%$.

Upaya pengendalian $M$. graminicola sangat penting dilakukan agar kerusakan pada tanaman padi dapat berkurang. Berbagai macam pengendalian telah banyak dilakukan terhadap M. graminicola pada tanaman padi (Sunarto et al. 2019). Salah satu pengendalian efektif dan ramah lingkungan yang dapat digunakan ialah pengendalian biologi. Bakteri endofit diketahui sebagai agens hayati yang mampu mengendalikan nematoda secara efektif pada berbagai macam tanaman pertanian. Munif et al. (2013) melaporkan bakteri endofit Pantoea agglomerans MK29, P. putida MT-19, Cedecea davisae MK-30, Enterobacter spp. MK-42 dapat menekan dan mengurangi populasi $M$. incognita pada akar tanaman tomat. Bakteri endofit Bacillus megaterium secara efektif mampu menghambat terjadinya penetrasi dan pembentukan puru akar M. graminicola pada tanaman padi (Padgham dan Sikora 2006). Anita dan Samiyappan (2012) melaporkan bakteri endofit Pseudomonas fluorescens dapat menekan pertumbuhan M. graminicola dengan menghasilkan enzim pendegradasi di dalam jaringan akar tanaman padi. Selain itu, P. fluorescens mampu menginduksi ketahanan tanaman padi terhadap serangan nematoda.

Aplikasi bakteri endofit yang sering dilakukan pada tanaman ialah aplikasi tunggal berupa perendaman benih. Aplikasi ganda dengan kombinasi perendaman benih dan penyiraman suspensi bakteri endofit belum banyak dilakukan terutama pada tanaman padi. Beberapa hasil penelitian melaporkan aplikasi ganda bakteri endofit dapat memberi hasil yang lebih baik dalam mengendalikan Meloidogyne. Selain itu, penggunaan bakteri endofit yang berasal dari berbagai varietas tanaman padi belum banyak dilakukan untuk mengetahui pengaruhnya terhadap M. graminicola. Tujuan penelitian ini ialah mengevaluasi potensi bakteri endofit yang berasal dari tanaman padi dan tanaman kentang dalam mengendalikan $M$. graminicola pada tanaman padi.

\section{BAHAN DAN METODE}

\section{Uji Kultur Filtrat Bakteri Endofit Terhadap Larva Meloidogyne graminicola secara in vitro}

Isolat bakteri endofit yang digunakan ialah Si2, Si33, Sp24, GH1 yang berasal dari padi gogo varietas lokal asal Pringsewu, Lampung dan G053 berasal dari tanaman kentang varietas Granola asal Garut, Jawa Barat. Uji kultur filtrat bakteri endofit mengikuti prosedur Padgham dan Sikora (2006). Isolat bakteri endofit ditumbuhkan di medium nutrient broth (NB) yang dikocok menggunakan alat shaker dengan kecepatan $100 \mathrm{rpm}$ pada suhu ruang selama 24-48 jam. Suspensi bakteri kemudian disentrifugasi dengan kecepatan 5000 rpm selama 20 menit. Proses sentrifugasi akan membentuk supernatan dan pelet. Supernatan bakteri endofit diambil sebanyak $4 \mathrm{~mL}$ dan dicampur dengan $0.5 \mathrm{~mL}$ suspensi larva juvenil 2 (kerapatan 100-200 ekor) di dalam cawan petri steril dan diinkubasi di dalam kondisi suhu ruang selama 24 jam. Selanjutnya, campuran tersebut disaring dengan penyaring ukuran 500 mesh. Suspensi nematoda diberi aerasi dengan aerator selama beberapa menit untuk mengetahui kondisi nematoda hidup atau mati. Perhitungan mortalitas dilakukan dengan menghitung jumlah juvenil 2 yang 
mati menggunakan mikroskop stereo. Data uji in vitro dianalisis sidik ragam dan uji lanjut Duncan multiple range test (DMRT) pada taraf kepercayaan $95 \%$ dengan program software statistical analysis system (SAS versi 9.3).

\section{Uji Bakteri Endofit Terhadap Meloidogyne graminicola di Rumah Kaca}

Benih padi yang digunakan pada pengujian ini ialah varietas Ciherang. Benih padi diberi perlakuan air panas selama 15 menit pada suhu $50{ }^{\circ} \mathrm{C}$ (Ventura dan Garrity 1987) dan direndam di dalam suspensi bakteri endofit (kerapatan $10^{8}-10^{9} \mathrm{cfu} \mathrm{mL}^{-1}$ ) selama 6 jam. Perlakuan bakteri endofit ini mengikuti prosedur Munif et al. (2013) yang dimodifikasi, yaitu perendaman benih (seed treatment) dan penyiraman suspensi bakteri di perakaran (soil drench). Perendaman benih dilakukan selama 6 jam dan ditanam ke dalam media tanam di polybag ukuran $25 \times 10 \mathrm{~cm}$. Media tanam yang digunakan ialah campuran tanah, pasir dan kotoran sapi yang matang dengan perbandingan 1:1:1 (v/v). Setelah benih padi berumur 10 hari, sebanyak $20 \mathrm{~mL}$ suspensi bakteri (kerapatan bakteri mencapai

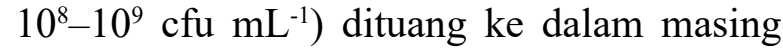
masing polybag. Pada saat tanaman padi berumur 15-16 hari, masing-masing tanaman diinokulasi dengan 1000 ekor juvenil 2 $M$. graminicola. Pengamatan dilakukan enam minggu setelah inokulasi nematoda. Parameter yang diamati ialah jumlah anakan, tinggi tanaman, jumlah puru akar, bobot akar, dan bobot tajuk. Data pengujian rumah kaca dianalisis sidik ragam dan uji lanjut DMRT (Duncan multiple range test) pada taraf kepercayaan 95\% menggunakan program software statistical analysis system (SAS versi 9.3).

\section{HASIL}

\section{Pengaruh Kultur Filtrat Bakteri Endofit Terhadap Larva Meloidogyne graminicola secara in vitro}

Kultur filtrat bakteri endofit sangat efektif membunuh juvenil 2 M. graminicola secara in vitro. Rata-rata persentase tingkat mortalitas juvenil 2 mencapai $99.3 \%$ hingga $100 \%$ (Tabel 1). Berdasarkan pengamatan secara mikroskopik menunjukkan dinding tubuh juvenil $2 M$. graminicola tidak mengalami kerusakan (lisis) yang disebabkan oleh kultur filtrat bakteri endofit. Toksin yang dihasilkan oleh isolat G053 dapat mengakibatkan terjadinya kerusakan organ dalam tubuh juvenil 2 M. graminicola (Gambar 1a). Bagian dalam juvenil $2 \mathrm{M}$. graminicola lisis dan rusak oleh kultur filtrat bakteri endofit, sedangkan tubuh juvenil 2 yang tidak diberi perlakuan tidak mengalami kerusakan (Gambar 1b).

\section{Pengaruh Bakteri Endofit Terhadap Meloidogyne graminicola pada percobaan di Rumah Kaca}

Aplikasi isolat bakteri endofit mampu menurunkan jumlah puru akar secara signifikan terhadap infeksi $M$. graminicola pada tanaman padi di percobaan di rumah kaca dibandingkan dengan kontrol. Persentase penurunan jumlah puru akar oleh isolat bakteri endofit berkisar $42.7 \%-49.2 \%$ dan tidak menunjukkan perbedaan yang signifikan antarperlakuan isolat bakteri (Tabel 2). Jumlah puru akar M. graminicola pada akar padi oleh perlakuan bakteri endofit berkisar 64 puru per sistem akar (rumpun) atau 16 puru per g akar jauh lebih kecil dibandingkan dengan jumlah puru akar pada kontrol, yaitu 120 puru per sistem akar atau rumpun.

Bakteri endofit yang digunakan dalam percobaan rumah kaca ialah suspensi bakteri endofit yang merupakan campuran dari hasil metabolisme bakteri endofit atau kultur filtrat dan sel bakteri hidup. Hal ini berbeda dengan percobaan in vitro yang menggunakan kultur filtrat bakteri endofit yang diduga mengandung

Tabel 1 Mortalitas juvenil 2 Meloidogyne graminicola pada perlakuan kultur filtrat bakteri endofit pada 24 jam setelah perlakuan

\begin{tabular}{lc}
\hline $\begin{array}{l}\text { Perlakuan isolat } \\
\text { bakteri endofit }\end{array}$ & Mortalitas (\%) \\
\hline Si2 & $99.3 \mathrm{a}$ \\
Si33 & $99.6 \mathrm{a}$ \\
Sp24 & $100.0 \mathrm{a}$ \\
G053 & $100.0 \mathrm{a}$ \\
GH1 & $100.0 \mathrm{a}$ \\
Kontrol & $3.2 \mathrm{~b}$ \\
\hline
\end{tabular}

Angka pada kolom yang sama dan diikuti huruf yang sama tidak berbeda nyata menurut uji DMRT pada $\alpha 5 \%$. 

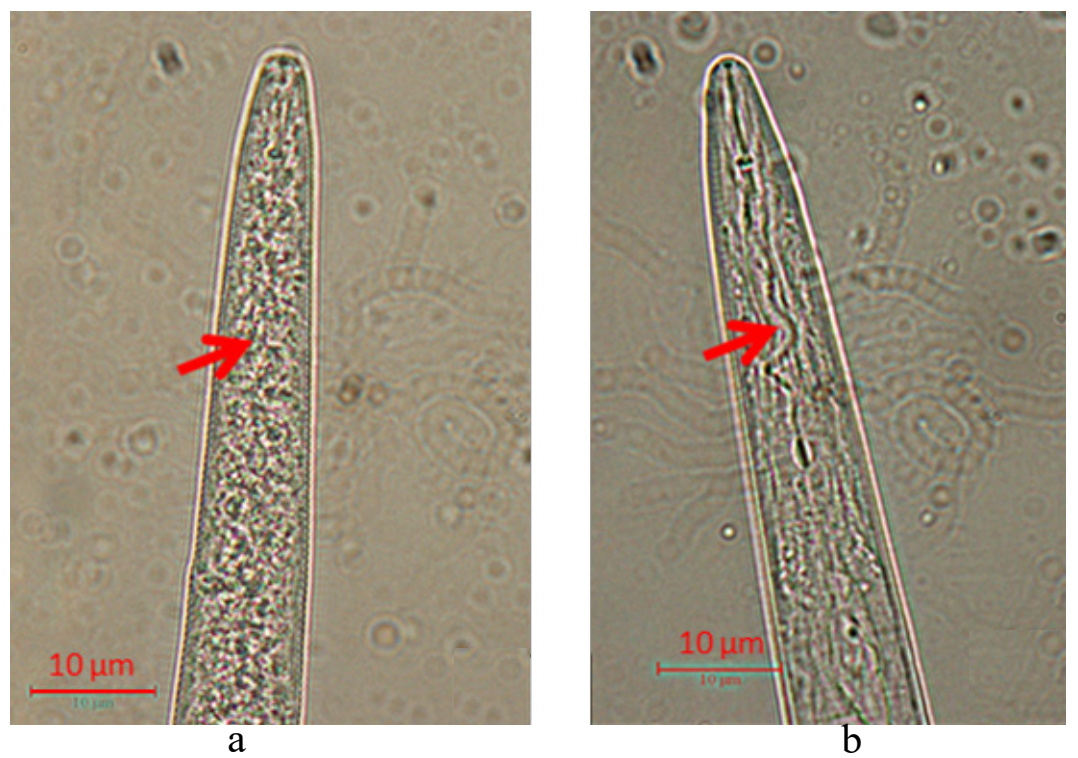

Gambar 1 Morfologi larva juvenil 2 Meloidogyne graminicola setelah diberi kultur filtrat dengan perbesaran 1000×. a, Isolat bakteri endofit G053; dan b, Tanpa diberi perlakuan.

Tabel 2 Jumlah puru akar Meloidogyne graminicola pada perlkuan bakteri endofit pada tanaman padi di rumah kaca

\begin{tabular}{lcc}
\hline $\begin{array}{l}\text { Perlakuan isolat } \\
\text { bakteri endofit }\end{array}$ & $\begin{array}{c}\text { Jumlah puru akar } \\
\text { per sistem akar }\end{array}$ & $\begin{array}{c}\text { Penurunan Jumlah Puru Akar } \\
(\%)\end{array}$ \\
\hline Si2 & $66.09 \mathrm{~b}$ & 44.9 \\
Si33 & $60.98 \mathrm{~b}$ & 49.2 \\
Sp24 & $68.78 \mathrm{~b}$ & 42.7 \\
G053 & $63.23 \mathrm{~b}$ & 47.3 \\
GH1 & $64.17 \mathrm{~b}$ & 46.5 \\
Kontrol & $120.16 \mathrm{a}$ & 0.0 \\
\hline
\end{tabular}

Angka pada kolom yang sama dan diikuti huruf yang sama tidak berbeda nyata menurut uji DMRT pada $\alpha 5 \%$.

efek nematisidal dari hasil antibiosis bakteri endofit selama proses inkubasi.

\section{Pengaruh Bakteri Endofit Terhadap Pertumbuhan Tanaman Padi di Rumah Kaca}

Hasil pengamatan menunjukkan secara umum isolat bakteri endofit tidak memberi pengaruh yang nyata dalam memicu pertumbuhan tanaman padi. Isolat bakteri yang digunakan tidak mampu meningkatkan tinggi dan panjang akar tanaman padi. Isolat bakteri endofit yang memicu pertumbuhan hanya terlihat pada jumlah anakan saja. Isolat $\mathrm{Si} 2$ yang mampu menghasilkan jumlah anakan yang paling banyak dibandingkan dengan isolat lain maupun kontrol (Tabel 3).

Semua isolat bakteri endofit tidak memberikan pengaruh yang signifikan juga terhadap peningkatan bobot basah dan kering tanaman padi. Bobot basah tajuk terhadap semua perlakuan memiliki nilai yang tidak berbeda nyata dengan kontrol bahkan isolat $\mathrm{Si} 2$ dan $\mathrm{GH} 1$ memiliki nilai lebih rendah dibandingkan dengan kontrol. Hasil ini berbeda pada bobot kering tajuk yang memiliki perbedaan hasil dengan kontrol. Isolat G053 dan Si33 memiliki bobot kering tajuk yang paling tinggi. Pengamatan terhadap akar tanaman padi pada semua perlakuan bakteri menunjukkan bobot basah dan bobot kering akar lebih rendah dibandingkan dengan kontrol (Tabel 4).

\section{PEMBAHASAN}

Kultur fitrat seluruh isolat bakteri endofit yang digunakan dalam penelitian ( $\mathrm{Si}$, 
Tabel 3 Pengaruh Bakteri Endofit terhadap jumlah anakan, tinggi tanaman, dan panjang akar tanaman padi di rumah kaca

\begin{tabular}{lccc}
\hline Perlakuan & Jumlah anakan padi & Tinggi Tanaman & Panjang Akar \\
\hline Si2 & $4.7 \mathrm{a}$ & $65.2 \mathrm{a}$ & $25.5 \mathrm{a}$ \\
Si33 & $3.9 \mathrm{~b}$ & $66.6 \mathrm{a}$ & $24.4 \mathrm{a}$ \\
Sp24 & $3.6 \mathrm{~b}$ & $69.1 \mathrm{a}$ & $24.7 \mathrm{a}$ \\
G053 & $4.1 \mathrm{~b}$ & $67.3 \mathrm{a}$ & $26.1 \mathrm{a}$ \\
GH1 & $3.9 \mathrm{~b}$ & $67.1 \mathrm{a}$ & $25 \mathrm{a}$ \\
Kontrol & $3.7 \mathrm{~b}$ & $69.2 \mathrm{a}$ & $24.2 \mathrm{a}$ \\
\hline
\end{tabular}

Angka pada kolom yang sama dan diikuti huruf yang sama tidak berbeda nyata menurut uji DMRT pada $\alpha 5 \%$.

Tabel 4 Pengaruh Bakteri Endofit terhadap bobot basah dan bobot kering tanaman padi di rumah kaca

\begin{tabular}{lccccc}
\hline \multirow{2}{*}{ Perlakuan } & \multicolumn{2}{c}{ Bobot Basah } & & \multicolumn{2}{c}{ Bobot Kering } \\
\cline { 2 - 3 } \cline { 5 - 6 } & Tajuk $(\mathrm{g})$ & Akar $(\mathrm{g})$ & & Tajuk $(\mathrm{g})$ & Akar $(\mathrm{g})$ \\
\hline Si2 & $12.4 \mathrm{a}$ & $3.4 \mathrm{~b}$ & & $4.4 \mathrm{~d}$ & $0.8 \mathrm{ab}$ \\
Si33 & $14.1 \mathrm{a}$ & $3.4 \mathrm{~b}$ & & $6.7 \mathrm{ab}$ & $0.8 \mathrm{~b}$ \\
Sp24 & $14.9 \mathrm{a}$ & $4.6 \mathrm{a}$ & & $6.1 \mathrm{bc}$ & $1.1 \mathrm{a}$ \\
G053 & $15.8 \mathrm{a}$ & $4.2 \mathrm{ab}$ & & $7.4 \mathrm{a}$ & $0.9 \mathrm{ab}$ \\
GH1 & $12.4 \mathrm{a}$ & $4.0 \mathrm{ab}$ & & $4.9 \mathrm{~d}$ & $0.9 \mathrm{ab}$ \\
Kontrol & $14.3 \mathrm{a}$ & $4.7 \mathrm{a}$ & & $5.3 \mathrm{~cd}$ & $1.1 \mathrm{ab}$ \\
\hline
\end{tabular}

Angka pada kolom yang sama dan diikuti huruf yang sama tidak berbeda nyata menurut uji DMRT pada $\alpha 5 \%$.

Si33, Sp24, G053, GH1) sangat efektif dalam menyebabkan mortalitas juvenil 2 $M$. graminicola mencapai 99\%-100\%. Siddiqui (2002) melaporkan bahwa kultur filtrat bakteri endofit Bacillus subtilis dan Pseudomonas aeruginosa efektif membunuh juvenil 2 dan dapat menurunkan persentase penetasan telur $M$. javanica pada tanaman tomat. Kultur filtrat bakteri endofit yang dikeluarkan memiliki potensi sebagai agens nematisida (Vetrivelkalai et al. 2012). Kultur filtrat bakteri endofit menghasilkan senyawa metabolit sekunder yang bersifat toksik (Siddiqui 2002). Toksin menjadi salah satu senyawa yang mampu meningkatkan mortalitas Meloidogyne (Mekete et al. 2009). Toksin yang dihasilkan oleh bakteri endofit diduga masuk ke dalam tubuh nematoda melalui lubang mulut dan mengakibatkan gangguan fisiologi pada nematoda. Kematian nematoda ditandai dengan kondisi tubuh nematoda sudah tidak bergerak lagi dengan tubuh kaku dan lurus.

Pengujian isolat bakteri endofit dengan aplikasi ganda memiliki potensi sebagai agens biokontrol M. graminicola. Munif et al. (2013) melaporkan penggunaan aplikasi ganda bakteri endofit terhadap benih tanaman tomat dapat meningkatkan kepadatan bakteri antagonis di dalam tanah. Metode perendaman benih tomat dapat menempatkan bakteri endofit pada permukaan benih dan melindungi benih pada saat berkecambah. Metode penyiraman suspensi bakteri endofit mampu menambah jumlah bakteri endofit di ujung akar yang terus tumbuh dan diduga dapat meningkatkan aktivitas antagonis mikroba.

Quadt-Hallmann et al. (1997) melaporkan mekanisme bakteri endofit mampu masuk ke dalam benih kapas melalui dua mekanisme. Mekanisme pertama, yaitu bakteri endofit yang menempel di atas permukaan benih mampu terserap masuk secara pasif ke dalam benih kapas. Mekanisme kedua ialah bakteri endofit mampu menghidrolisis dinding sel benih kapas dengan mengeluarkan enzim selulosa dan pektin. Bakteri endofit dapat juga masuk ke dalam jaringan internal akar melalui penyiraman suspensi bakteri. Compant et al. (2005) melaporkan bakteri Burkholderia mampu mengolonisasi akar Vitis vinifera. Burkholderia paling banyak ditemukan di bagian ujung akar dan akar lateral dan mampu masuk melalui degradasi dinding sel dengan enzim endoglucanase dan endopolygalacturanase. 
Mekanisme bakteri endofit dalam menekan pertumbuhan Meloidogyne di dalam jaringan tanaman dapat berupa antibiosis, enzimatik dan induksi ketahanan. Anita dan Samiyappan (2012) melaporkan bahwa bakteri endofit $P$. fluorescens mampu menghasilkan fenol dan enzim peroxidase (PO), polyphenol oxidase (PPO), phenyl ammonia lyase (PAL), super oxide dismutase (SOD) dan kitinase yang dapat menghambat $M$. graminicola di dalam akar tanaman padi. Kemampuan nematisida yang dimiliki oleh bakteri endofit mampu menstimulasi juga terbentuknya ketahanan berupa induced systemic resistance (ISR) pada tanaman inang (Elbanna et al. 2010). Ketahanan ISR muncul ketika tanaman diinduksi bakteri endofit atau bakteri nonpatogenik di dalam jaringannya (Kloepper dan Ryu 2006). Bukti adanya ISR dapat dilihat dengan adanya asam salisilat dan peroksidase setelah kolonisasi bakteri endofit di dalam tanaman (Harni dan Ibrahim 2011).

Aplikasi ganda bakteri endofit dengan perendaman benih dan penyiraman suspensi bakteri endofit di akar tidak berpengaruh terhadap peningkatan pertumbuhan tanaman padi. Hal ini diduga kerapatan dan volume suspensi bakteri endofit terlalu rendah. Hal berbeda dilaporkan Munif et al. (2013) bahwa aplikasi ganda bakteri endofit mampu meningkatkan pertumbuhan dan menekan jumlah puru akar Meloidogyne pada tanaman tomat. Banyak hasil penelitian yang telah melaporkan peranan bakteri endofit dalam memacu pertumbuhan tanaman. Kemampuan bakteri endofit dalam meningkatkan pertumbuhan tanaman dapat dilihat dengan adanya hormon indole acetic acid (IAA), melarutkan fosfat, memproduksi $\mathrm{HCN}$, memproduksi siderofor, dan menghasilkan asam sianida (Etesami et al. 2014). Fungsi lain manfaat bakteri endofit di dalam tanaman ialah adanya penyesuaian osmotik, regulasi buka-tutup stomata, modifikasi morfologi akar, peningkatan asupan mineral, perubahan dari akumulasi nitrogen dan metabolisme tanaman (Compant et al. 2005).

Pengendalian biologi baik dengan memanfaatkan bakteri endofit maupun dengan pemanfaatan ekstrak tanaman yang mengandung efek biopestisida untuk mengendalikan nematoda puru akar $M$. gramincola pada padi perlu terus dikembangkan mengingat padi adalah komoditas yang strategis di Indonsia. Sunarto et al (2019) melaporkan penggunaan ekstrak daun bayam duri, daun beluntas, kirinyuh, dan eceng gondok dapat mempengaruhi penetrasi nematoda $M$. graminicola ke area perakaran tanaman padi menurunkan penyakit puru akar yang disebabkan oleh $M$. graminicola pada tanaman padi. Aplikasi ekstrak daun tersebut pada tanaman padi mengakibatkan induksi resistensi sistemik ditunjukkan dengan penurunan jumlah puru pada akar tanaman padi.

Hasil penelitian ini memberikan indikasi yang kuat bahwa isolat bakteri endofit GH1, Si2, Si33, Sp24, dan G053 yang digunakan dalam penelitian ini memiliki potensi sebagai agens biokontrol untuk $M$. graminicola pada tanaman padi berdasarkan uji in vitro dan rumah kaca. Penelitian lanjutan terkait pemanfaatan bakteri endofit untuk pengendalian $M$. graminicola pada sistem padi sawah dan sistem padi gogo perlu dikembangkan.

\section{DAFTAR PUSTAKA}

Anita B, Samiyappan R. 2012. Induction of systemic resistance in rice by Pseudomonas fluorescens against rice root knot nematode Meloidogyne graminicola. J Biopest. 5:53-59.

Compant S, Duffy B, Nowak J, Clement C, Barka EA. 2005. Use of plant growthpromoting bacteria for biocontrol of plant diseases: principles, mechanisms of action, and future prospects. App Environ Microbiol. 71(9):951-4959. DOI: https://doi.org/10.1128/AEM.71.9.49514959.2005.

Elbanna K, Gamal-Eldin H, Abuzaed E. 2010. Characterization of egyptian fluorescent rhizosphere pseudomonad isolates with high nematicidal activity against the plant parasitic nematode Meloidogyne incognita. J Biofertil Biopestic. 1(1):17. DOI: https://doi.org/10.4172/21556202.1000102 . 
Erlan. 1993. Distribusi dan patogenisitas nematoda Meloidogyne cf. graminicola pada tanaman padi sawah di Daerah Istimewa Yogyakarta [tesis]. Yogyakarta (ID): Universitas Gajah Mada.

Etesami H, Hosseini M, Alikhani HA. 2014. In planta selection of plant growth promoting endophytic bacteria for rice (Oryza sativa L.). J Soil Sci Plant Nutr. 14(2):491-503. DOI: $\quad$ https://doi.org/10.4067/S071895162014005000039.

Harni R, Ibrahim MSD. 2011. Potensi bakteri endofit menginduksi ketahanan tanaman lada terhadap infeksi Meloidogyne incognita. J Littri. 17(3):118-123. DOI: $\quad$ https://doi.org/10.21082/jlittri. v17n3.2011.118-123.

Jaiswal RK, Kumar D, Singh KP. 2012. Relationship between growth of rice seedlings and time of infection with Meloidogyne graminicola. Libyan Agric Res Cen J Int. 3(1):13-17.

Kloepper JW, Ryu CM. 2006. Bacterial endophytes as elicitors of induced systemic resistance. Di dalam: Schulz B, Boyle C, Sieber TN, editor. Microbial Root Endophytes. Berlin (DE): Springer-Verlag Berlin Heidelberg. hlm 33-50. DOI: https://doi.org/10.1007/3-540-33526-9_3.

Mekete T, Hallmann J, Kiewnick S, Sikora R. 2009. Endophytic bacteria from Ethiopian coffee plants and their potential to antagonist Meloidogyne incognita. Nematol. 11(1):117-127. DOI: https://doi. org/10.1163/156854108X398462.

Mulyadi. 1997. Pengaruh populasi nematoda puru akar (Meloidogyne graminicola) terhadap pertumbuhan dan hasil padi. JPTI. 3(1):17-22.

Munif A, Hallmann J, Sikora RA. 2013. The influence of endophytic bacteria on Meloidogyne incognita infection and tomato plant growth. J ISSAAS. 19(2): 68-74.

Nurjayadi MY, Munif A, Suastika. 2015. Identifikasi nematoda puru akar, Meloidogyne graminicola pada tanaman padi di Jawa Barat. J Fitopatol Indones. 11(4):113-120. DOI: https://doi. org/10.14692/jfi.11.4.113.
Padgham JL, Duxbury JM, Mazid AM, Abawi GS, Hossain M. 2004. Yield loss caused by Meloidogyne graminicola on lowland rainfed rice in Bangladesh. J Nematol. 36(1):42-48.

Padgham JL, Sikora RA. 2006. Biological control potential and modes of action of Bacillus megaterium against Meloidogyne graminicola on rice. Crop Protect. 26:971977. DOI: https://doi.org/10.1016/j. cropro.2006.09.004.

Pokharel RR, Abawi GS, Zhang N, Duxbury JM, Smart CD. 2007. Characterization of isolates of Meloidogyne from rice-wheat production fields in Nepal. J Nematol. 39(3):221-230.

Quadt-Hallmann A, Benhamou N, Kloepper JW. 1997. Bacterial endophytes in cotton: mechanisms of entering the plant. Can $\mathrm{J}$ Microbiol. 43:577-582. DOI: https://doi. org/10.1139/m97-081.

Ravindra H, Sehgal M, Narasimhamurthy HB, Jayalakshmi K, Khan HIS. 2017. Rice rootknot nematode (Meloidogyne graminicola) an emerging problem. Int J Curr Microbiol App Sci. 6(8):3143-3171. DOI: https:// doi.org/10.20546/ijcmas.2017.608.376.

Siddiqui IA. 2002. Suppression of Meloidogyne javanica by Pseudomonas aeruginosa and Bacills subtilis in tomato. Nematol mediterr. 30:125-130.

Sunarto T, Suganda T, Sianipar MS, Irwan AW. 2019. Ketahanan sistemik terinduksi pada tanaman padi dengan ekstrak tumbuhan terhadap nematoda bengkak akar (Meloidogyne graminicola Golden and Birchfiels). J Agrikultura. 30(1):25-32. DOI: https://doi.org/10.24198/agrikultura. v30i1.22700.

Ventura AR, Garrity DP. 1987. Effect of hot water treatments on the quality of rice seed destined for international exchange 1. Crop science. 27(2):278-283. DOI: https://doi. org/10.2135/cropsci1987.0011183X00270 0020032x.

Vetrivelkalai P, Sivakumar M, Jonathan EI. 2010. Biocontrol potentional of endophytic bacteria on Meloidogyne incognita and its effect on plant growth in bhendi. J Biopest. $3(2): 452-457$. 